\title{
The Concept of Smart-Education for Sustainable Development
}

\author{
Nataliya A. Burmistrova \\ Financial University \\ Moscow, Russia \\ bur_na_a@mail.ru
}

\author{
Natalya V. Vasina \\ Financial University \\ Moscow, Russia \\ NVasina75@list.ru
}

\author{
Alexandra P. Shmakova \\ Financial University \\ Moscow, Russia \\ shmackova.alex@yandex.ru
}

\author{
Viacheslav A. Filimonov \\ Financial University \\ Sobolev Institute of Mathematics \\ $S B R A S$ \\ Omsk, Russia \\ filimonov-v-a@yandex.ru
}

\author{
Nadezhda I. Ilina \\ Financial University \\ Moscow, Russia \\ ila-jah@yandex.ru
}

\author{
Irina V. Kalnitskaya \\ Financial University \\ Moscow, Russia \\ IVKalnitskaya@fa.ru
}

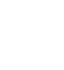

\begin{abstract}
The issue of the advancement of modern education in the context of sustainable development is significant. The reason for this is that the introduction of the ideas and principles of sustainable development into the content of education is a prerequisite for the implementation of sustainable development strategies. This goal contributes to the establishment of moral principles in the society and environmental responsibility. In turn, the necessity of elaboration of a concept of Smart-education for sustainable development is determined by globalization of education and lifelong learning. The timeliness of this study is due to the lack of comprehensive research of Smart-education in the context of sustainable development. However, the availability of some scientific publications in the field of Smart-education, which include a description of system solutions and technologies in the field of education, results in conceptual ambiguities of Smart-education. The authors' approach to the formulation of the concept of Smart-education for sustainable development has been presented. The goal of Smart-education includes the implementation of three main aspects. One of these aspects is aimed at sustainable development of the society and economy in accordance with the changing environment. Another aspect creates conditions for acquiring knowledge and skills which are required in the contemporary society. The third aspect determines the formation of a personality who is able to develop on a continuous basis and assess the impact of decisions made in a multivariate and uncertain environment. The conceptual ideas of Smart-education for sustainable development (principles, methodological tools, structural components) have been identified.
\end{abstract}

Keywords - Smart-education, principles of Smart-education, sustainable development

\section{INTRODUCTION}

The concept of sustainable development and its three main components that include economic growth, social development and environmental balance have provided a framework for sustainable development of higher education since the end of the last century [1]. The term "sustainable development" was first used in the report of the World Commission on Environment and Development: Our Common Future in 1987. Norwegian Prime Minister G.H. Brundtland defined sustainable development as "development that meets the needs of the present without compromising the ability of future generations to meet their own needs" [2]. In contemporary studies sustainable development is thought of as a global project in which everyone should be involved in building up a sustainable future [3]. Nowadays, there are more than 100 definitions of the term "sustainable development". The main aim of such development is to meet the needs of the society through sound management of physical, natural and human capital [4].

Smart-education is a key component of the modern educational paradigm - "lifelong learning" [5]. According to Leuven Communiqué, lifelong learning involves extending knowledge, gaining new skills and competences, obtaining qualifications and enriching personal growth, the successful implementation of which should include procedures for the recognition of prior learning. The development of the European lifelong learning should be understood as a network activity. Many interested parties are engaged in this activity. In this regard, the formulation of the concept of Smart-education for sustainable development associated with internationalization and globalization of education is at the top of the agenda of international organizations, national governments, universities, research organizations and student communities. 


\section{Problem StATEMENT}

The importance of this study is determined by the relevance of raising the following questions in research works:

1. How does the paradigm of "lifelong learning" change the modern educational conceptual foundation? [6]

2. How can sustainability be interpreted from the perspective of educational policy-making? [7]

3. What is the future of academic e-learning? [8]

4. Has my professional knowledge become out of date? Do I have the skills necessary to meet the new challenges of the society? What kind of knowledge do I lack to qualify for a job that I like? [9]

P. Maresca, A. Guercio, L. Stanganelli, T. Arndt note that the question of solving complex problems caused by globalization is the most challenging one [10]. It includes education, economic development, environment protection and others. It is obvious that nowadays there are no ready-made solutions of these problems. In this regard, it is necessary to form the collaborative ideas of education development under the current socio-economic conditions.

The authors' approach to the formulation of the concept of Smart-education for sustainable development, which was presented in the study, is aimed at solving the abovementioned problems.

\section{RESEARCH QUESTIONS}

The study is devoted to working out the conceptual ideas of Smart-education for sustainable development. At the same time, the most important thing is to place greater focus on cultivation of independent-minded and motivated young people who are able to live and work in the ever-changing world.

\section{A. The goal of Smart-education}

The goal of Smart-education for sustainable development is to provide a basis for acquiring new knowledge. The focus is based on information technologies that allow achieving new socioeconomic and environmental impact on the education system.

According to the authors of this study, the concept of Smart-education should correspond to the model of education for sustainable development. This involves the transfer of the educational process into the electronic environment. The interactive environment that combines educational organizations and the academic teaching staff to carry out educational activities is conducive to the effectiveness of the training. International trends in higher education show a shift from the teacher-centered model to the student-centered model that focuses on what students know and what they can do.

The results of the analysis of studies [7], [4] revealed that the goal of Smart-education for sustainable development includes the implementation of three main aspects:

1. Sustainable development of the society and economy in accordance with the changing environment.
2. Creation of an environment for competitive education by means of acquiring knowledge and skills which are required in the contemporary society.

3. Formation of a personality who is able to develop on a continuous basis and assess the impact of decisions made in a multivariate and uncertain environment.

\section{B. The principles of Smart-education}

Smart-education for sustainable development is based on the following theoretical approaches.

A system-based approach. Smart-education is a set of interrelated elements considered as a whole and is a part of a higher tier of the education system.

An integrated approach. Creation of an education space which enables students to get the necessary knowledge, skills and competencies on the basis of information and media technologies.

A human relations approach. The human element plays a major role in Smart-education.

The concept of Smart-education is also determined by the classical principles of education:

- the recognition of the priorities of education;

- $\quad$ non-discrimination in education;

- humanistic values in education, full development of the human personality, fostering mutual respect, civic consciousness, patriotism, responsibility, legal culture and rational use of natural resources;

- creating conditions for realization of personal potential, free development of his / her abilities that includes granting of the right to choose the mode of study;

- granting teachers the freedom to choose the methods and tools of teaching;

- ensuring full access to the right to lifelong learning, the adaptability of the education system to the attainment levels, special needs, individual abilities and interests.

Taking into account the above-mentioned, we can highlight the principles of Smart-education for sustainable development:

1. Goal-setting. The goal of education is primary, because it is a source of relations, on the basis of which students, teachers, administration and other agents establish a relationship and begin to implement educational activities.

2. Social dimension. Equitable access to education.

3. Student-centered learning. Empowerment of students, introduction of new teaching approaches, the creation of an effective system of support and leadership.

4. Openness of higher education system. Internationalization of European higher education institutions and their participation in global cooperation for sustainable development. 
5. Mobility. Flexible educational paths and the individualization of the learning process.

6. The implementation of the process of education in a distributed learning environment. The process of education should be continuous, including learning in a professional environment with the use of professional tools.

\section{PURPOSE OF THE STUDY}

The goal of Smart-education for sustainable development is achieved by means of the following components: a Smartuniversity, a Smart-teacher and a Smart-student.

\section{A. The structural components of Smart-education}

A Smart-university is a university in which the combination of technological innovations and the Internet leads to the new quality of processes and results of educational, research, social and other activities.

The goal of a Smart-university is to teach students how to live up to the most progressive ideas and cultural values, to master ways of acquiring new knowledge and skills of search for relevant information. In other words, a Smart-university is a socially oriented university that meets the requirements of a Smart-society.

The role of both the student and the teacher changes within the concept of Smart-education. The student is not a passive element and focuses on the development of key competencies such as information selection, teamwork, self-management and self-assessment. It should be noted that the concept of Smarteducation is based on the idea of individualization of learning. It can be achieved by means of the creation of the content aimed at a particular student. For this purpose, a new knowledge object is identified and described. The arrays of objects allow the teachers to put them together and create unique content that meets the needs of an individual student. Learning content enables students to get skills and knowledge in accordance with the competence-based model. Thus, within the framework of the Smart-education concept, the teacher develops an individualized approach for each student. Moreover, the student can participate in the development of some course units; he/she can choose the Smart-teaching methods which suit his/her personal needs and preferences. For the previous reasons, it can be said that a Smart-teacher and a Smart-student are the participants of the process of education where the Smart-technologies are used to achieve the new quality of education that meets the requirements of a Smartsociety.

\section{B. The methodological tools of Smart-education}

In accordance with the classic approach, the method is a set of means aimed at achieving a goal. This, in turn, allows us to define the Smart-education method as a set of educational technologies that use the advantages of the global information society to provide educational services of a new quality. The methodological tools of the concept of Smart-education for sustainable development include two components: Smartlearning and scientific potential of teachers.
Smart-learning means a set of methods for the organization of educational activities with the use of information that is contained in databases and information technologies that process it. These methods are aimed at the interaction of students and teachers. The use of Smart-learning methods leads to the emergence of a world where there are no barriers to the generation, exchange and dissemination of knowledge. This is due to the development of the Internet and new information technologies that minimize the number of links on the way of knowledge from its generation to innovation implementation. With the help of digital technologies, which are the part of the network society, universities create and disseminate knowledge and contribute to lifelong learning of citizens [11].

The importance of Smart-learning methods in higher education is growing. It is related to the fact that their use meets the needs of students who live in the digital world, promotes pedagogical innovations, exchange of knowledge and cooperation at different levels. These methods can be employed by an unlimited number of users in all regions and countries of the world.

It cannot be denied that there is a positive relationship between the use of Smart-learning methods in the process of education and the students engagement in the attainment of learning goals ([12], [13]. [14], [15]). The diversity of Smartlearning methods in scientific publications is presented by elearning, online learning and mobile learning.

There are many new opportunities for conducting research in the field of digital learning. The work of E. Sosa Neira, J. Salinas, B. De Benito presents an analysis of studies related to the development of information technologies in education for the period from 2006 to 2016 [16]. The results of the analysis show that the studies were aimed at improvement of the process of education through the advancement of information technologies. The second component of the methodological tools of the Smart-education concept is the development of scientific potential of teachers.

The problem of the links between education and science has been discussed for a long time. Scientific research and education are directly related to the quality of these activities, which has been given the highest priority in recent decades. Teachers need a certain degree of academic freedom to achieve high-quality scientific results. We share the opinion of $\mathrm{N}$. Shmatko and G. Volkova that if the incentive of scientists is self-fulfillment, gaining new skills and competencies, then the professional environment should support them and use these intellectual resources effectively [17]. The use of Smartlearning methods reduces the teaching load. As a result, teachers have time for scientific activities.

Summing up, it should be noted that the methodological tools of Smart-education are the key components of the competitiveness of universities in the national and international markets of educational services.

\section{ReSEARCH Methods}

To detail the integrated components of the concept of Smart-education for sustainable development, the theoretical 
analysis of the studies of Russian and foreign scientists that are devoted to the problem under consideration, has been conducted. The authors' approach to the formulation of the concept of Smart-education for sustainable development has been proposed. This enables the authors to give scientific and applied interpretation of the obtained results.

\section{FINDINGS}

In the course of the research, the conceptual ideas of Smarteducation for sustainable development including the goal methodological tools, principles, structural components, have been identified (Fig.1).

\begin{tabular}{|l|l|l|}
\hline \multicolumn{2}{|c|}{ Smart-education } \\
\hline & & \\
\hline
\end{tabular}

\section{The goal}

1. Sustainable development of the society and economy in accordance with the changing environment.

2. Creation of an environment for competitive education by means of acquiring knowledge and skills of the contemporary society.

3. Formation of the personality who is able to develop on a continuous basis and assess the impact of decisions made in a multivariate and uncertain environment.

\section{Principles}

Goal-setting, social dimension, student-centered learning, openness of higher education system, mobility, implementation of the education process in a distributed learning environment

\section{The methodological tools}

Smart-learning (e-learning, online learning and mobile learning), scientific potential of teachers

\section{The structural components}

Smart-university, Smart-teacher, Smart-student

Fig.1. The conceptual ideas of Smart-education for sustainable development

\section{CONCLUSION}

To sum up, it is important to note that the implementation of the concept of Smart-education for sustainable development cannot solve all the problems facing our society today. Nevertheless, these conceptual ideas represent a holistic approach aimed at developing students' skills and abilities that are required for active participation in society, education and work. This study proved that the implementation of the concept of Smart-education increases the educational potential of universities, and it ensures multilevel lifelong learning.

The proposed concept of Smart-education is dynamic. In its development, the concept takes into account national traditions and it can easily adapt to a new environment. The methodological tools of Smart-education develop together with the improvement of Smart-technologies.

\section{REFERENCES}

[1] T. Savelyeva and W. Douglas, Global consciousness and pillars of sustainable development: A study on self-perceptions of the firstyear university students. International Journal of Sustainability in Higher Education, vol. 18, no 2, pp. 218-241, 2017. doi:https://doi.org/10.1108/IJSHE-04-2016-0063

[2] G. H. Brundtland, Global change and our common future. Environment, vol. 31, no 5, pp. 16-43, 1989. doi:10.1080/00139157.1989.9928941

[3] M. Ideland, and C. Malmberg, 'Our common world' belongs to 'Us': constructions of otherness in education for sustainable development. Critical Studies in Education, vol. 55, no 3, pp. 369386, 2014. doi:10.1080/17508487.2014.936890

[4] N. A. Burmistrova, E. A. Kormiltseva, A. P. Shmakova, and M. A. Loshchilova, An Innovative Approach to Education in the Context of Sustainable Development. The European Proceedings of Social \& Behavioural Sciences, vol. XXVI, pp. 122-129, 2017. doi:http://dx.doi.org/10.15405/epsbs.2017.07.02.16

[5] S. Roche, Sum ergo disco: The ubiquity of learning (in non-formal and informal settings). International Review of Education, vol. 63, no 3, pp. 297-301, 2017. doi:http://doi.org/10.1007/s11159-0179648-z

[6] P. Ricaurte, Pedagogies for the open knowledge society. International Journal of Educational Technology in Higher Education, vol. 13, no 32, 2016. doi:http://doi.org/10.1186/s41239016-0033-y

[7] M. Milana, P. Rasmussen, and J. Holford, Societal sustainability: The contribution of adult education to sustainable societies. International Review of Education, vol. 62, no 5, pp. 517-522, 2016. https://doi.org/10.1007/s11159-016-9595-0

[8] H. Fischer, L. Heise, M. Heinz, K. Moebius, and T. Koehler, How to identify e-learning trends in academic teaching: Methodological approaches and the analysis of scientific discourses. Interactive Technology and Smart Education, vol. 12, no 1, pp. 31-43, 2015. https://doi.org/10.1108/ITSE-09-2014-0031

[9] D. Baneres and J. Conesa, A Life-long Learning Recommender System to Promote Employability. International Journal Of Emerging Technologies In Learning, vol. 12, no 6, pp. 77-93, 2017. doi:http://dx.doi.org/10.3991/ijet.v12i06.7166

[10] P. Maresca, A. Guercio, L. Stanganelli, and T. Arndt, Experiences in Collaborative Learning. Journal of e-Learning and Knowledge Society, vol. 10, no 3, 2014. doi:https://doi.org/10.20368/1971$8829 / 961$

[11] I. Rodríguez-Ardura and A. Meseguer-Artola, What leads people to keep on e-learning? An empirical analysis of users' experiences and their effects on continuance intention. Interactive Learning Environments, vol. 24, no 6, pp. 1030-1053, 2016. doi: $10.1080 / 10494820.2014 .926275$

[12] C. Goh, C. Leong, K. Kasmin, P. Hii, and O. Tan, Students' Experiences, Learning Outcomes and Satisfaction in eLearning. Journal of e-Learning and Knowledge Society, vol. 13, no 2. 117-128, 2017. doi:https://doi.org/10.20368/1971-8829/1298

[13] A. Al-Alwani, Information Technology Integration in Higher Education: A Novel Approach for Impact Assessment. International Journal Of Emerging Technologies In Learning, vol. 9, no 6, pp. 32 36, 2014. doi:http://dx.doi.org/10.3991/ijet.v9i6.4036

[14] M. Abbad and F. Jaber, Evaluating E-Learning Systems: An Empirical Investigation on Students' Perception in Higher Education Area. International Journal Of Emerging Technologies In Learning, vol. 9, no 4, pp. 27-34, 2014. doi:http://dx.doi.org/10.3991/ijet.v9i4.3480

[15] N. El-Khalili and H. El Ghalayini, Comparison of Effectiveness of Different Learning Technologies. International Journal Of Emerging Technologies In Learning, vol. 9, no 9, pp. 56-63, 2014. doi:http://dx.doi.org/10.3991/ijet.v9i9.4158

[16] E. Sosa Neira, , J. Salinas, \& B. De Benito, (2017). Emerging Technologies (ETs) in Education: A Systematic Review of the Literature Published between 2006 and 2016. International Journal Of Emerging Technologies In Learning, vol. 12, no 5, pp. 128-149. doi:http://dx.doi.org/10.3991/ijet.v12i05.6939 
N. Shmatko and G. Volkova Service or Devotion? Motivation Patterns of Russian Researchers. Foresight and STI Governance, vol. 11, no 2 , pp. 54-66, 2017. DOI: 10.17323/25002597.2017.1.54.66 